\title{
Radiation-Induced Recombination
}

National Cancer Institute

\section{Source}

National Cancer Institute. Radiation-Induced Recombination. NCI Thesaurus. Code C20156.

Any recombination occurring in response to DNA breakage induced by ionizing radiation, and resolved with possible exchange and frequent loss of segments of DNA by either homologous recombination or non-homologous end-joining of broken DNA strands. This process is involved in sustaining viability among cells that are irradiated, and occurs frequently at the expense of long-term genomic stability. 